\title{
Assets Development of Video History Learning Based Animated 2.5d for Students SMPN 7 Depok
}

\author{
Ulfah Nur Izzati, Ade Rahma Yuly \\ JurusanTeknikInformatikadanKomputer \\ PoliteknikNegeri Jakarta \\ ulfah.nur.tik14@ mhsw.pnj.ac.id, de.rohima@gmail.com
}

Diterima: 10 September 2018. Disetujui: 20 November 2018. Dipublikasikan November 2018

\begin{abstract}
The history lesson is boring" is an assumption often raised by school students. Most history teachers still use lecture methods in class while there are many other methods that can be used to convey historical material. Based on the survey results of 8th grade students of SMPN 7 Depok thought that learning history would be more fun if using video animation and students also need animation video as one of the means of learning. 2.5D animated video created based on history lesson material for 8th grade students namely chapters Changes of Indonesian society during the colonial era and the growth of national spirit sub chapters of the arrival of the western nation. Assets of characters and background images are based on course material, are made in 2D using the image tracing method. The test is done by visual analog scale method. The test results show that the assets made in the form of characters and background make it easier for students to understand the material in the video.
\end{abstract}

Keywords: audio, asset, tracing, video learning.

\section{INTRODUCTION}

The problem often encountered by students in history lessons is the difficulty of visualizing and composing the information conveyed because this lesson contains abstract, complex, and elusive past information[8]. The method of delivering material used by teachers also influences the level of students' enthusiasm for history lessons [1]. The results of the pre-test that has been done to the eighth graders of SMPN 7 Depok shows that $38 \%$ of students consider history lesson boring. Therefore required a method of learning in the form of visual media so that students are more motivated in learning history. The making of a historical animation f video requires $2 \mathrm{D}$ elements or asset images based on references that correspond to historical events. The tracing technique can be used in the manufacture of image assets for short animated films because with this technique it can produce the same character expression as the reference image [2]. In this study, the image asset for historical animation video created using tracing techniques makes the face of historical figures to be exactly the same as the reference photograph used.

\section{LITERATURE REVIEW}

\section{Animation}

The animation is an interface that combines text, graphics, and sound in a movement activity, and as a technology that can make a still image into a moving image look as if the image is alive, moving, acting and saying [3]. An article explains that basically, the 2.5-dimensional animation is a $2 \mathrm{D}$ animation in $3 \mathrm{D}$ space. Thus the $\mathrm{Z}$-axis in this $2.5 \mathrm{D}$ animation is a pseudo $\mathrm{Z}$ axis and can only be felt from the front perspective of frame [4].

\section{Illustration}

Picture or illustration is a result of the visual cultivation of the writings or ideas possessed by an illustrator who aims to explain a story or phenomenon of events [5]. Illustrative artists or pictures usually have their own style in their works. The style of drawing is a collection of attributes that make the image unique [6].
3. Colour
The definition of color objectively or physically as the nature of light emitted or 
subjectively or psychologically as part of the sense-ofsight experience [7].

\section{Visual Analogue Scale}

VAS is a useful measurement instrument for classifying subjective phenomena such as perceptions related to aesthetics and evaluation of pain intensity [8]. VAS consists of horizontal or vertical lines along 100 millimeters. The value is translated into four or five categories of phenomena. Numerous studies have shown that respondents are guided by the principle of equi-section, the cognitive subdivision within the same interval. VAS data can be analyzed by various statistical approaches based on the type of data retrieved and the end result to be achieved [9].VAS can also avoid a better ceiling effect than the Likert scale [5].

\section{DES IGN AND REALIZATION}

Asset creation is one stage in the production process of an animated video. However, before making asset, creation required the design of the animated video to be made. The design of assets in the form of characters, environment and audio narration used in the video.

\section{A. Animated Video Design}

\section{Description of Animation Video.}

The animated video to be created is a visualization of the history lesson material for the 8th grade SMP. Based on the method of Villamil Molina, the goal and target set and concept development for a multimedia product are done at the Development stage.

A study of 8th-grade junior high school students has been conducted to determine the goals and objectives of the video to be made. The result of the research shows that the 8th grade IPS teacher in SMPN 7 Depok has never used animation video as a learning media, while $86 \%$ of students stated that they need the animated video to learn history. Therefore, the purpose of this animated video is as a medium for learning history.

After the goals and objectives are formed, a video concept is developed. The video concept to be created is a $2.5 \mathrm{D}$ animated history-based learning video. This animated video will visualize one of the sub-chapters of historical material entitled "The Entrance of the West to Indonesia".

The 2D illustration concept consists of artboard size, image style, theme color, font type. The artboard used in the illustration is $1280 \times 720 \mathrm{px}$ because the end result of the animated video will be 720px. The drawing style used is hand-drawing to depict historical figures and place backgrounds. The theme colors used are classic and pastel colors as shown in Figure 1. These colors are chosen to match the theme of the animated video history.

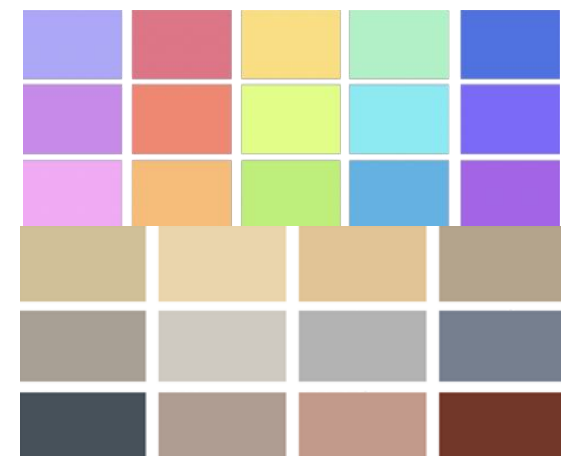

Figure 1. Example of A Pastel Palette (Left) And Classic (Right) used.

In Figure 2 we can see the shape of the font

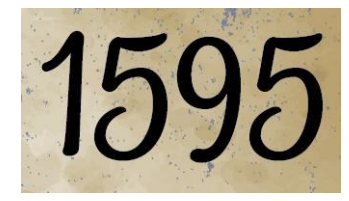

Figure 2. Font Money Penny Script

Figure 3 illustrates the workflow of creating an animated video asset.

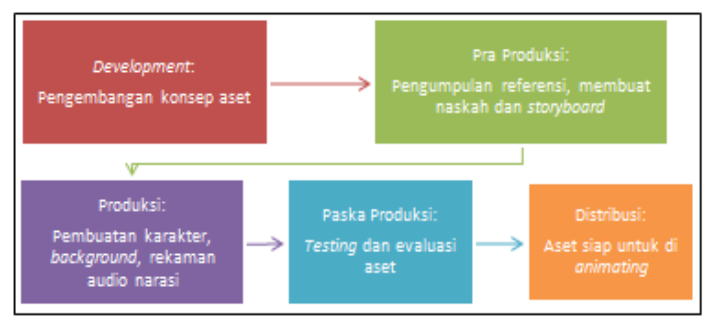

Figure 3. Animated Video Asset Creation Workflow

\section{Animated Video Design.}

Based on the Villamil Molina method, the animated video design is included in the Preproduction stage.

\section{Material Collection.}

Historical lesson material was taken from BSE IPS book for 8th-grade junior high school students published by the government. The sub-chapter title that will be visualized in the video is "The Coming of the West". 


\section{Narrative Script.}

Prior to the making of the manuscript, the subject matter of the history of the arrival of the western nations contained in the book of IPS BSE for junior high school students of class 8 was broken down into important points that contained the flow of events. Historical material points will be developed into a narrative. The narrative is divided into short narratives for each scene in the animated video. In addition, the script will be recorded and used as a voice-over in the animated video.

\section{Storyboard.}

Storyboard is based on the pre-existing narrative script. The storyboard is divided into scenes. Each scene consists of several shots. Each shot contains illustrations, narrative pieces and directions for visual effects and animating. Figure 4 shows some storyboards from the $2.5 \mathrm{D}$ animated video that will be created.

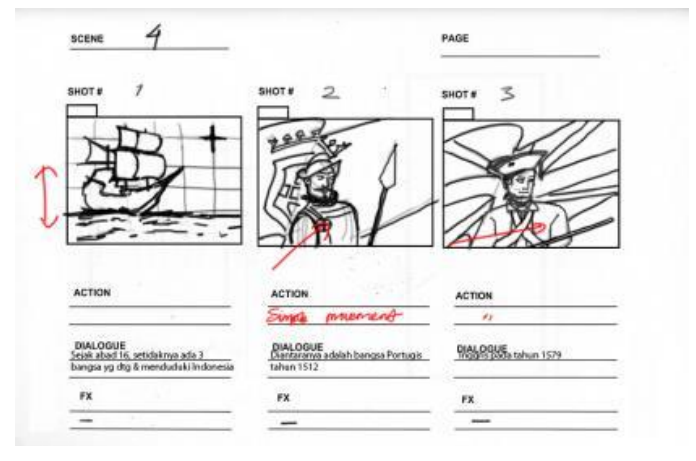

Figure 4. Some Storyboards of Animated Video

\section{B. Asset Realization}

\section{Creation of Animated Video Character.}

Characters are made based on reference images in the form of paintings or photos of the face of historical figures. The technique of tracing is used in making face figures. This technique was chosen to shorten the face-making time of historical figures and produce images that are similar to references but in vector formats. In the process, the reference image is imported into the artboard page of the Adobe Illustrator software as a reference for tracing. Tools used for tracing are pencil tool and pen tool. Figure 5 (a) shows the tracing results of the reference image and tracing result will look like in Figure 5(b).
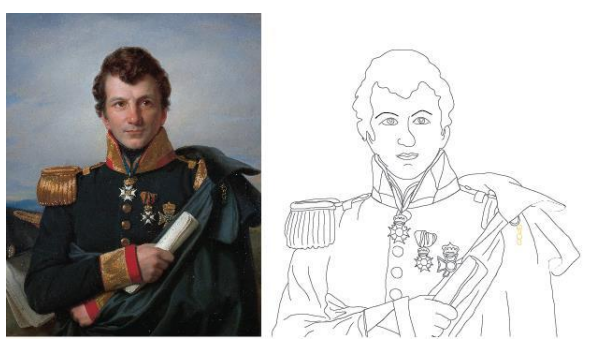

(a)

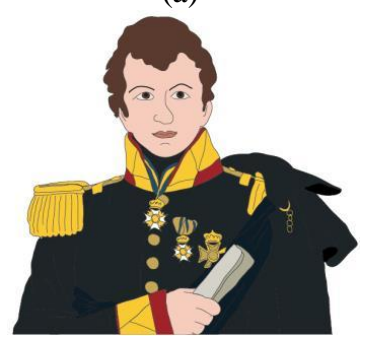

(b)

Figure 5. (a) Reference Images and Tracing Results, (b) Face of A Colored Figure

\section{Background Video Animation Creation.}

Background or background image in a $2.5 \mathrm{D}$ animation video is a visualization of the narrative and is based on a storyboard. The techniques used in making the background will be explained in the points below.

\section{a. Tracing of reference images.}

The background that uses this technique is the background that displays the logo. However, no highresolution reference images are found for some logos. Therefore tracing logo done so that the resulting as set is not broken. Figure 6 shows (a) a reference image of a low-resolution EIC logo that will be used and (b) the end result of tracing the EIC logo.

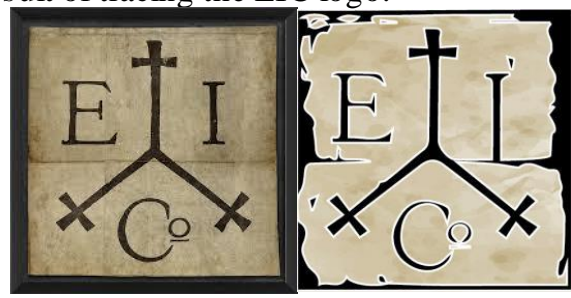

Figure 6. (a) Reference Image; (b) The End Result of EIC Logo Tracing

b. Rebuild Illustration. The purpose of reproducing an illustration is the creation of a background image with an atmosphere or composition similar to the reference image used. But the resulting image does not exactly match the reference image. An example of a 
background using this technique can be seen in Figure 7.

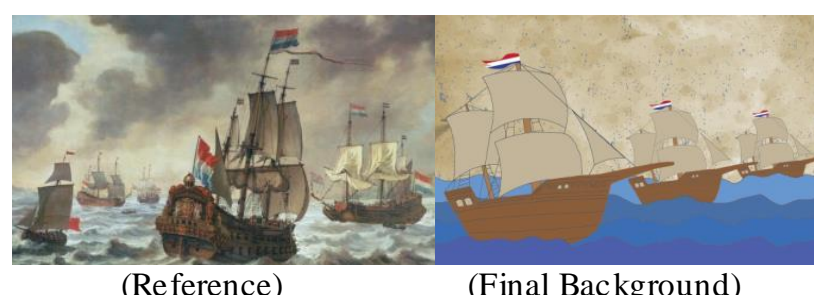

Figure 7. Examples of Backgrounds That They Re-Draw Reference Images

\section{TES TING AND ANALYS IS}

\section{A. Test Procedure}

1. Alpha Testing. Assets of characters, background images, and written narratives are shown to the internal team. The internal team will comment on the completed asset whether it is feasible for the animating. If the asset is deemed worth, then the asset will be submitted to the animating section.

2. Beta Testing. The goal of making this $2.5 \mathrm{D}$ animated video is the junior high school students of SMPN 7 Depok. Students will be asked to answer the pre-test questions about the historical material contained in the animation video as much as two questions. After finishing the questions, students are not told whether their answers are right or wrong. Students are then asked to watch the 2.5D animated video. After the video is finished, the students are again asked to answer the post-test questions. The question of post-test consists of four questions, two of which are new, taken from historical material in the $2.5 \mathrm{D}$ animated video they previously watched. The results of the post-test will be compared with the pretest results through the Wilcoxon test in the SPSS application. After following the pre-test and post-test, students are given a questionnaire to assess the quality of the $2.5 \mathrm{D}$ animated video.

\section{B. Data Testing Result}

1. Results of Alpha Testing. The internal team finds some form of character asset that will complicate the animating process. In addition, also found character assets and background images for some scenes that are not placed per layer so it will complicate the process of animating.
2. Results of Beta Testing. The result of beta testing is divided into two, namely pre-test post-test and questionnaire of 2.5D animation video. Respondents for pre-test post-test consisted of 38 people. The correct answer to every question is worth 25 points. The pre-test and post-test scores were tested by normality tests to determine whether or not the data distribution was normal. Table 1 shows the result of the normality test using the SPSS application to pretest score and post-test.

TABLE 1. NORMALIT Y TEST RESULT S OF PRE-TEST AND POST -TEST SCORES

\begin{tabular}{|c|c|c|c|c|c|c|}
\hline & \multicolumn{3}{|c|}{ Kolmogorov- Smirnov ${ }^{a}$} & \multicolumn{3}{|c|}{ Shapiro-Wilk } \\
\hline & Statistic & $\mathrm{df}$ & Sig. & Statistic & $\mathrm{df}$ & Sig. \\
\hline $\begin{array}{l}\text { Pre-test } \\
\text { Score }\end{array}$ &, 526 & 24 &, 000 & ,316 & 34 &, 000 \\
\hline $\begin{array}{l}\text { Post- } \\
\text { test } \\
\text { Score }\end{array}$ & ,362 & 24 & ,000 & ,636 & 24 &, 000 \\
\hline
\end{tabular}

After the normality test, the pre-test and posttest scores were also tested by Wilcoxon test on SPSS application to find out the increase of students score before and after watching $2.5 \mathrm{D}$ animation video. Figure 8 shows the score ratings before and after watching the video.

\begin{tabular}{|cc|c|c|c|}
\hline & N & $\begin{array}{c}\text { Mean } \\
\text { Rank }\end{array}$ & $\begin{array}{c}\text { Sum of } \\
\text { Ranks }\end{array}$ \\
\hline $\begin{array}{c}\text { Skor Posttest - } \\
\text { Skor Pretest }\end{array}$ & $\begin{array}{c}\text { Negative } \\
\text { Ranks } \\
\text { Positive } \\
\text { Ranks }\end{array}$ & $0^{n}$ &, 00 &, 00 \\
& $23^{\text {Ties }}$ & $1^{\mathrm{c}}$ & 12,00 & 276,00 \\
& 24 & & \\
& Total & 24 & \\
\hline
\end{tabular}

Figure 8. Ranking of pre-test score and post-test

After knowing the pre-test and post-test scores, the statistical results of the Wilcoxon test using the SPSS application are shown in Figure98. The analysis results from this table will show the effect of watching the video on the score or vice versa.

\begin{tabular}{|l|r|}
\hline & Skor Posttest - Skor Pretest \\
\hline$Z$ & $-4,335^{a}$ \\
Asymp. Sig. (2-tailed) &, 000 \\
\hline
\end{tabular}

Figure 9. Wilcoxon statistical test results

After the pre-test and post-test are performed, students are required to complete the assessment questionnaire. Of the 24 respondents, pre-test and post-test participants were only 22 students who filled in the questionnaire and only 20 people completed the questionnaire. Questionnaire assessment using the Visual Analog Scale. Results of VAS data from 0-100 each have a defined range of meanings by dividing the 
length of the scale by the number of interpretation categories.

C. Data Analysis / Evaluation

Alpha Testing

From the test results performed by the internal team, the characters in the error are corrected. After assets are fixed, assets are channeled to the animating team.

\section{Beta Testing}

Table 1 shows that the value of Sig. for pre-test and post-test score is 0,000 , which means that data is not normally distributed. Therefore it can not be paired T-test because the data is not eligible. Replacement of paired T-test for data that is not normally distributed is a Wilcoxon test. The hypothes is in this research is that there is a change of learning result of 8th-grade students of SMPN7 Depok before and after watching the video.

Based on the results in Figure 8 it can be seen that the Negative Ranks is worth 0 . That is, there is no decrease in the score from pre-test to post-test. The result of the Wilcoxon test can be seen in Figure 9. In the figure, the value of Asymp.Sig. (2-tailed) is 0,000. Value 0.000 s maller than 0.05 , it can be concluded that the hypothesis accepted. This means that there is a positive influence of the use of 2.5D learning-based animated learning videos on the outcomes of students of grade 8 SMPN 7 Depok. Table 2 shows the result of questioner.

TABLE 2. RESULT

\begin{tabular}{|l|c|l|}
\hline Questions & Average & Conclude \\
\hline $\begin{array}{l}\text { Q1. Are the character's } \\
\text { drawings (face or } \\
\text { person's face) used in } \\
\text { this video make it easy } \\
\text { to recognize characters } \\
\text { and remember } \\
\text { hist orical events? }\end{array}$ & 76 & $\begin{array}{l}\text { Video allows } \\
\text { students to } \\
\text { recognize } \\
\text { characters and } \\
\text { remember } \\
\text { hist orical events }\end{array}$ \\
\hline $\begin{array}{l}\text { Q2. Are the } \\
\text { background and } \\
\text { writing images used in } \\
\text { this video make it easy } \\
\text { to remember historical } \\
\text { events? }\end{array}$ & 87 & $\begin{array}{l}\text { The background } \\
\text { image and naration } \\
\text { make it easier to } \\
\text { remember } \\
\text { historical events. }\end{array}$ \\
\hline $\begin{array}{l}\text { Q3. Are the characters, } \\
\text { background images } \\
\text { and writing that appear } \\
\text { to help you understand } \\
\text { the content of the } \\
\text { video being told }\end{array}$ & 90 & $\begin{array}{l}\text { The characters, } \\
\text { background } \\
\text { images, and } \\
\text { naration are very } \\
\text { helpful to } \\
\text { understanding the } \\
\text { content of the } \\
\text { video being told }\end{array}$ \\
\hline $\begin{array}{l}\text { Q4. Do you think the } \\
\text { color used in the video } \\
\text { is good to see }\end{array}$ & 83 \\
\hline $\begin{array}{l}\text { Q5. Do you think the } \\
\text { underst ion is read easily }\end{array}$ & 85 & $\begin{array}{l}\text { The color used in } \\
\text { the video is very } \\
\text { pleasing to see }\end{array}$ \\
\hline
\end{tabular}

\section{Asset Distributions}

Assets are completed and testing will be distributed for animation.

\section{CONCLUS IONS AND RECOMMENDATIONS}

Based on the process of making a $2.5 \mathrm{D}$ animated video-based learning asset for junior high school students who have done, can be drawn conclusion form.

1. This research succeeded in making assets in the form of characters, background images, and audio in accordance with the steps in the method of Villamil-Molina.

2. Based on the results of pre-test and post-test testing of $2.5 \mathrm{D}$ animated video, found that the positive effect of the use of 2.5D-based animated history learning videos on the results of students' learning grade 8 SMPN 7 Depok.

3. Based on alpha testing results, the assets created are valid and can be continued to the animating stage.

4. Based on the results of beta testing, respondents agree that characters and backgrounds can help in remembering historical events. And facilitate students in understanding the material. Respondents also agree that audio assets are heard clearly.

We recommend that the material visualized into a $2.5 \mathrm{D}$ animated video is the whole chapter of historical material.

\section{REFERENCES}

[1] Nair, S. M. and Narayanasamy , M., 2017. "The Effects of Utilising the Concept Maps in Teaching History". International Journal of Instruction , 10(3), 109-126.

[2] Anggriawan, B., 2013. "Pe mbuatan Film Bergenre Drama Remaja Dengan Menggabungkan Teknik Tracing Vector Dan Motion Tracking Berjudul Obsesi". STIKOM Institutional Respository.

[3] Munir, 2013. Multimedia Konsep dan Aplikasi Dalam Pendidikan. Bandung: Alfabet.

[4] Maulana, Vian Ade, 2016. "Pembuatan Film Animasi 2,5D Bergenre Drama Tentang Berkurangnya Populasi Hewan Akibat Penebangan Liar Untuk Anak Sekolah Dasar". STIKOM Instutional Respository.

[5] Voutilainen, A., Pitk€aaho, . T., Kvist, T. and Vehvil€ainen-Julkunen, . K., 2015. "How to ask about patient satisfaction? The visual analogue scale is less vulnerable to confounding factors and ceiling effect than a symmetric Likert scale". 
Journal of Advanced Nursing , 72(4), 946-957.

[6] Hoddinott, B. and Combs, J., 2011. Drawing for Dummies. 2nd Edition. Indianapolis: Wiley Publishing.

[7] Nugroho, S., 2015. Manajemen Warna dan Desain. Yogyakarta: CV Andi Offset.

[8] Rosas, S., Pa co, . M., Lemos, . C. and Pinho, . T., 2017. "Comparison between the Visual Analog Scale and the Numerical Rating Scale in the perception of esthetics and pain". International Orthodontics, Volu me 15, 543-600.

[9] Heller, G., Z., Manuguerra, M. dan Chow, R., 2016. "How To Analyze The Visual Analogue Scale: Mhyths, Truths And Clinical". Scandinavian Journal of Pain, 67-75. 